\title{
DIMENSI HAM DAN HUKUM ISLAM DALAM PUTUSAN MAHKAMAH KONSTITUSI NO. 46/PUU-VIII/2010
}

\author{
Imam Mustofa \\ STAIN Jurai Siwo Metro Lampung \\ Email: moostofa@yahoo.com
}

\section{Abstract}

This paper describes the dimensions of Human Rights (HAM) enforcement in the Constitutional Court decision of number 46/PUU-VIII/2010. Two important things wbich are considered because law discosrse development, especially the law of marriage in Indonesia resembling Constitutional Court's decision of number 46/PUU-VIII/2010 that affirmed protection of buman rights of all citizens backgrounds without primordial. The result of the analysis is expected to create a comprebensive understanding of the bumtan rights dimension of the of Constitutional Count's decision of number 46/PUU-VTI/2010 and create an objective and comprebensive understanding that the decision was not contraty to the provisions of Islamic lav.

\section{مستخفلصن}

هذه المقالة باحثة عن إقامة حقوق الإنسانية في قرار مجكمة الدستور رقم VIII

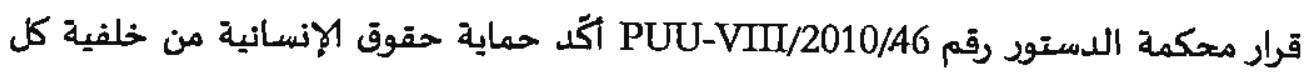
هجتمع آلّولة دون بدأي.

Keywords: HAM, Hukum Islam, Perkawinan, Anak.

\section{A. Pendahuluan}

Mahkamah Konstitusi sebagai institusi kekuasaan kehakiman di Indonesia pada tanggal 27 Februari 2012 membuat keputusan No.46/PUU-VII/2012 
terkait kedudukan hukum bagi anak luar nikah. Putusan Mahkamah Konstitusi tersebut lahir karena adanya permohonan yudisial review yang diajukan oleh $\mathrm{Hj}$. Aisyah Mokhtar dan anaknya yang bernama Muhammad Iqbal Ramadhan bin Moerdiono terhadap ketentuan Pasal 2 ayat (2) dan Pasal 43 ayat (1) Undangundang Nomor 1 Tahun 1974 tentang Perkawinan, dimana Moerdiono sebagai seorang suami yang telah beristri menikah kembali dengan istrinya yang kedua bemama $\mathrm{Hj}$. Aisyah Mokhtar secara syari'at Islam dengan tanpa dicatatkan dalam register Akta Nikah, oleh karena itu ia tidak memiliki Buku Kutipan Akta Nikah, dan dari pernikahan tersebut lahir seorang anak laki-laki yang bernama Muhammad Iqqbal Ramdhan Bin Moerdiono.'

Latar belakang putusan ini adalah anak yang dilahirkan mengalami diskriminasi dan tidảk mendapatkan pengakuan hubungan keperdataan sebagai "anak" dari ayah dan keluarga ayahnya karena pernikahan ibunya tidak dicatatkan. Hal ini disebutkan dalam pasal 43 ayat 1 UU No. 1/1974 yang menyatakan bahwa "Anak yang dilahirkan diluar perkawinan hanya mempunyai hubungan perdata dengan ibunya dan keluarga ibunya." Pasal ini dikuatkan dengan pasal 100 Kompilasi Hukum Islam yang berbunyi "Anak yang dilahirkan di luar perkawinan hanya mempunyai hubungan perdata dengan ibunya dan keluarga ibunya". Ketentuan ini menimbulkan kesan, sekan-akan kedudukan wanita yang melahirkan anak tersebut tidak seimbang dengan kedudukan pria yang menghamilinya. Jika ditinjau dari segi si anak, malah menimbulkan kesan tidak adil dan tidak manusiawi. Hukum kita memang tidak mengenal lembaga pengakuan dan pengesahan anak. Ini merupakan dilema yang sulit dipecahkan. Sebab, jika anak yang tidak sah (yang dilahirkan di luar perkawinan) diberi juga status hukum terhadap bapak alaminya, maka seluruh lembaga perkawinan yarig begitu luhur akan berantakan sama sekali. ${ }^{2}$

1 Syamsul Anwar dan Isak Munawar, "Nasab Anak di Luar Perkawinan Paska Putusan Mahkamah Konstitusi Nomot 46/PUU-VII/2010 Tanggal 27 Pebruari 2012 menurut Teori Fikih dan Petundang-Undangan.", dikutip dati http://www.badilag.mahkamahagung.go.id diunduh tanggal 12 mei 2012 hal, 1.

2 Bustanul Arifin, Pelembagaan Hukum Islam di Indonesia: Akar Sejarah, Hambatan, dan Prospeknya, (Jakarta: Gema Insani Press, 1996), hal. 124. 
Akibat pemberlakuan pasal 43 ayat (1) di atas, maka seorang istri dan anak. yang lahir dari sebuah perkawinan yang tidak dicatatkan atau anak yang lahir dari sebuah hubungan di luar perkawinan maka hak-hak dasarnya sebagai manusia akan terbengkalai dan terabaikan. Seorang Istri yang digauli tidak dalam sebuah pernikahan dan melahirkan seorang anak maka akan menerima konsekuensi, antara lain: pertama, negara tidak memberikan perlindungan serta merugikan bagi perempuan dan anak. Kedua, bagi perempuan, dianggap bukan istri yang sah katena tidak memiliki bukti otentik. Ketiga, istri tidak berhak atas nafkah, harta gono-gini dan warisan. Keempat, anak tidak berhak atas nafkah dan warisan. Kelima, hal yang paling merugikan bagi adalah tidak diakuinya hubungan dengan bapak biologis. Namun dengan dikeluarkannya Putusan Mahkamah Konstitusi No. 46/PUU-VIII/2010, nampaknya konsekuensi di atas tidak lagi berlaku. Putusan ini memiliki dampak yang cukup besar dalam penerapan beberapa aturan hukum di Negara Republik Indonesia. Putusan tersebut mempengaruhi beberapa aturan materil yang selama ini dijadikan sebagai rujukan dalam mengadili sebuah perkara di pengadilan. ${ }^{3}$.

Putusan Mahkamah Konstitusi No. 46/PUU-VIII/2010 tersebut berusaha menegakkan menjamin dan melindungi hak-bak konstitusional dan Hak Asasi Manusia (HAM) setiap warga negara yang telah dilindungi oleh UndangUndang Republik Indonesia. Putusan tersebut menguatkan jaminan hak setiap setiap warga negara untuk melaksanakan perkawinan serta mendapatkan perlindungan dan hak-haknya sebagai seorang istri. Lebih jauh, putusan tersebut juga memberikan jaminan dan perlindungan hak-hak setiap anak yang lahir, baik dari sebuah perkawinan yang sah maupun tidak. Hak untuk mendapatkan kehidupan yang layak, perlindungan dan perlakuan yang sama di hadapan hukum.

Tulisan ini mengeksplorasi dan memaparkan dimensi penegakan Hāk Asasi Manusi (HAM) dalam putusan Mahkamah Konstitusi No. 46/PUU-VIII/2010. tersebut. Lebih lanjut, tulisan ini juga membahas tentang pergulatan putusan

${ }^{3}$ Rio Satria, "Kritik Analisis Tentang Putusan Mahkamah Konstitusi Mengenai Uji Materil Undang-Undang Nomor 1 Tahun 1974 Tentang Perkawinan", dikutip dari http://www.badilag.mahkamahagung.go.id diunduh tanggal 12 mei 2012, hal. 1. 
tersebut dengan aturan-aturan yang ada dalam hukum Islam. Dua hal ini penting untuk dibahas karena membuka wacana perkembangan hukum, terutama hukum perkawinan di Indonesia yang secara bersamaan, putusan MK tersebut juga menegaskan perlindungan HAM terhadap semua warga negara tanpa melihat latar belakang primordialnya.. Lebih lanjut, penulisan ini bertajuan: pertama, agar tercipta pemahaman yang komprehensif di di kalangan masyarakat, khususnya akademisi mengenai dimensi-dimensi penegakan HAM dalam putusan Mahkamah Konstitusi No. 46/PUU-VII/2010. Kedua, terciptanya pemahaman yang obyektif dan, komprehensif bahwa putusan tersebut tidak bertentangan dengan ketentuan-ketentuan hukum Islam, khususnya terkait hubungan keperdataan yang diberikan putusan tersebut terhadap anak yang lahir bukan dari perkawinan yang sah atau akibat perzinaan.

\section{B. Sekilas Putusan Mahkamah Konstitusi No. 46/PUU-VIII/2010 tentang Pasal 43 Undang-Undang No. 1 tahun 1974 tentang Perkawinan}

Sebagai jawaban atas pengajuan uji materi terhadap Undang-Undang Perkawinan tahun 1974 pasal 2 ayat (2) ${ }^{4}$ dan pasal 43 ayat (1) ${ }^{5}$ Mahkamah Konstitusi Mengeluarkan Putusan No. 46/PUU-VII/2010. Putusan Mahkamah Konstitusi tersebut adalah suatu putusan final yang berkaitan dengan uji materiil undang-undang, Undang-Undang Nomor 1 Tahun 1974. Oleh karena itu Putusan MK ini berlaku sebagai undang-undang sehingga substansinya general, tidak individual dan tidak kasuistik, sesuai ketentuan Pasal 56 ayat $(3)^{6}$ jo Pasal 57 ayat $(1)^{7}$ UUMK. Putusan Mahakamah Konstitusi

4 "Tiap-tiap perkawinan dicatat menurut peraturan petundang- undangan yang berlaku."

5 "Anak yang dilahitkan diluar perkawinan hanya mempunyai hubungan perdata dengan ibunya dan keluarga ibunya".

6 Dalam hal permohonan dikabulkan sebagaimana dimaksud pada ayat (2), Mahkamah Konstitusi menyatakan dengan tegas materi muatan ayat, pasal, dan/atau bagian dari undangundang yang bertentangan dengan Undang-Undang Dasar Negara Republik Indonesia Tahun 1945.

${ }^{7}$ Putusan Mahkamah Konstitusi yang amas putusannya menyatakan bahwa materi muatan ayat, pasal, dan/atau bagian undang-undang bertentangan dengan Undang-Undang Dasar 
tersebut memiliki kekuatan mengikat terhadap seluruh masyarakat Indonesia sejak diucapkan dalam sidang terbuka untuk umum pada tanggal 27 Februari Tahun 2012 sesuai Pasal 47 UUMK dan dengan terbitnya putusan MK ini, maka ketentuan Pasal 43 ayat (1) dan Pasal $100 \mathrm{KHI}$ tidak memiliki kekuatan hukum mengikat. ${ }^{8}$

Pokok permasalahan yang diajukan pemohon dalam uji materi UU No. 1 tahun 1974 tentang Perkawinan adalah pasal 2 ayat (2) dan pasal 43 ayat-di atas. Berdasarkan pokok permohonan ini, maka Mahkamah Konstitusi berpendapat bahwa pokok permasalahan hukum mengenai pencatatan perkawinan menurut peraturan perundang-undangan adalah mengenai makna hukum (legal meaning) pencatatan perkawinan. Mengenai permasalahan tersebut, Penjelasan Umum angka 4 huruf b UU 1/1974 tentang asas-asas atau prinsipprinsip perkawinan menyatakan:

... bahwa suatu perkawinan adalah sah bilamana dilakukan menurut hukum masing-masing agamanya dan kepercayaannya itu; dan di samping itu tiap-tiap perkawinan harus dicatat menurut peraturan perundang-undangan yang berlaku. Pencatatan tiap-tiap perkawinan adalah sama halnya dengan pencatatan peristiwa-peristiwa penting dalam kehidupan seseorang, misalnya kelahiran, kematian yang dinyatakan dalam surat-surat keterangan, suatu akte yang juga dimuat dalam pencatatan. ${ }^{9}$

Berdasarkan Penjelasan UU $1 / 1974$ di atas nyatalah bahwa (i) pencatatan perkawinan bukanlah merupakan faktor yang menentukan sahnya perkawinan; ${ }^{10}$

Negara Republik Indonesia Tahun 1945, materi muatan ayat, pasal, dan/atau bagian undangundang tersebut tidak mempunyai kekuatan hukum mengikat.

${ }^{8}$ A. Mukti Arto, "Diskusi Hukum Putusan Mahkamah Konstitusi RI Nomor 46/PUUIIV/2010 Tanggal 27 Pebruari 2012 Tentang Perubahan Pasal 43 UUP", dikutip dari http://www.badilag.mahkamahagung.go.id diunduh tanggal 12 mei 2012, hal. 21.

9 Penjelasan Undang-Undang No. 1 tahun 1974 tentang Perkawinan mengenai prinsipprinsip perkawitnan. (Anonim, Undang-Undang Republik Indonesia Nomor 1 Tabut 1974 tentang Perkawinan dan Kompilasi Hukam Islam (Bandung: Citra Umbata, 2007), hal. 29-30).

10 Pada dasarnya, UUU No. 1 Tahun 1974 bukanlah aturan pertama tentang pencatatan perkawinan di Indonesia. Sebelumnya sudah ada UU No. 22 Tahun 1946 yang mengatur pencatatan nikah, talak dan rujuk, yang semula hanya berlaku di daerah Jawa dan Madura. Namun dengan lahirnya UU No. 32 Tahun 1954 yang disahkan pada 26 Oktober 1954, maka UU No. 22 tahun 1946 berlaku untuk seluruh wilayah Indonesia. (Lihat Khoiruddin Nasution, 
dan (ii) pencatatan merupakan kewajiban administratif yang diwajiblkan berdasarkan peraturan perundang-undangan. ${ }^{11}$ Adapun faktor yang menentukan sahnya perkawinan adalah syarat-syarat yang ditentukan oleh agama dari masing-masing pasangan calon mempelai. Diwajibkannya pencatatan perkawinan oleh negara melalui peraturan perundang-undangan merupakan kewajiban administratif. ${ }^{12}$ Aturan pencatatan perkawinan diantaranya dimaksudkan untuk menjamin hak-hak wanita dan tidak menjadi obyek diskriminasi laki-laki dengan jalan kawin cerai tanpa tanggung jawab. ${ }^{13}$

Makna pentingnya kewajiban administratif berupa pencatatan perkawinan tersebut, menurut Mahkamah, dapat dilihat dari dua perspektif. Pertama, dari perspektif negara, pencatatan dimaksud diwajibkan dalam rangka fungsi negara memberikan jaminan perlindungan, pemajuan, penegakan, dan pemenuhan hak asasi manusia yang bersangkutan yang merupakan tanggung jawab negara dan harus dilakukan sesuai dengan prinsip negara hukum yang demokratis yang diatur serta dituangkan dalam peraturan perundang-undangan.

Kedua, pencatatan secara administratif yang dilakukan oleh negara dimaksudkan agar perkawinan, sebagai perbuatan hukum penting dalam kehidupan yang dilakukan oleh yang bersangkutan, yang berimplikasi terjadinya akibat hukum yang sangat luas, di kemudian hari dapat dibuktikan dengan bukti" yang sempuina dengan suatu akta otentik, sehingga perlindungan dan pelayanan oleh negara terkait dengan hak-hak yang timbul dari suatu perkawinan yang bersangkutan dapat terselenggara secara efektif dan efisien. ${ }^{14}$

Mahkamah Konstitusi juga berpendapat bahwa secara alamiah, tidaklah mungkin seorang perempuan hamil tanpa terjadinya pertemuain antara ovum

Status Wanita di Asia Tenggara: Studi terbadap Penundang-Undangan Perkavinan Muslim Kontemporer di Mologusia dan Indonesia, (Jakarta: INIS, 2002), hal. 147.

11 Pencatatan perkawinan diatur lebih rinci dalam PP No. 9 Tahun 1975 pasal 2- 11. (Libat lebih lanjut Yusdani, Menuju Fiqib Keluarga Progresif, (Yogyakarta: Kaukaba, 2011), hal 96-102.

12 Putusan Mahkamah Konstituasi No. 46/PUU-VUI/2010, hal. 33.

13 Khoiruddin Nasution, "Pengaruh Gerakan Wanita tethadap Wacana Hukum Islam: Studi Hukum Perkawinan di Indonesia" dalam jurnal AL-MAWARDD, (Yogyakarta: FLAI UII, Edisi XIV tahun 2005), hal. 263.

14 Putusan Mahkamah Konstituasi ...., hal. 33-34 
dan spermatozoa baik melalui hubungan seksual (coitus) maupun melalui cara lain berdasatkan perkembangan teknologi yang menyebabkan terjadinya pembuahan. Oleh karena itu, tidak tepat dan tidak adil manakala hukum menetapkan bahwa anak yang lahir dari suatu kehamilan karena hubungan seksual di luar perkawinan hanya memiliki hubungan dengan perempuan tersebut sebagai ibunya. Adalah tidak tepat dan tidak adil pula jika hukum membebaskan laki-laki yang melakukan hubungan seksual yang menyebabkan terjadinya kehamilan dan kelahiran anak tersebut dari tanggung jawabnya sebagai seorang bapak dan bersamaan dengan itu hukum meniadakan hak-hak anak terhadap lelaki tersebut sebagai bapaknya. Lebih-lebih manakala berdasarkan perkembangan teknologi yang ada memungkinkan dapat dibuktikan bahwa seorang anak itu merupakan anak dari laki-laki tertentu. ${ }^{15}$ Berdasarkan hal ini dan berbagai pertimbangan, maka Pasal 43 ayat (1) UndangUndang Nomor 1 Tahun 1974 tentang Perkawinan (Lembaran Negara Republik Indonesia Tahun 1974 Nomot 1, Tambahan Lembaran Negara Republik Indonesia Nomor 3019) yang menyatakan, "Anak yang dilabirkan di luar perkawinan banya mempunyai bubungan perdata dengan ibunya dan keluarga ibunya", bertentangan dengan Undang-Undang Dasar Negara Republik Indonesia Tahun 1945 sepanjang dimaknai menghilangkan hubungan perdata dengan laki-laki yang dapat dibuktikan berdasarkan ilmu pengetahuan dan teknologi dan/atau alat bukti lain menurut hukum ternyata mempunyai hubungan darah sebagai ayahnya. Pasal tersebut menurut MK juga tidak memiliki kekuatan hukum mengikat sepanjang dimaknai menghilangkan hubungan perdata dengan lakilaki yang dapat dibuktikan berdasarkan ilmu pengetahuan dan teknologi dan/atau alat bukti lain menurut hukum ternyata mempunyai hubungan darah sebagai ayahnya, sehingga ayat tersebut harus dibaca, "Anak yang dilabirkan di luar perkawinan mempunyai bubungan perdata dengan ibunya dan keluarga ibunya serta dengan laki-laki sebagai ajabnya yang dapat dibuktikan berdasarkan ilmu pengetabuan dan teknologi dan/atau alat bukti lain menurut bukum mempunyai bubungan darab, termasuk bubungan perdata dengan keluarga ayabnya";

\footnotetext{
${ }^{15}$ Putusan Mahkamah Konstituasi .., hal. 35.

${ }^{16}$ Ibid., hal. 37.
} 
Putusan Mahkamah Konstitusi di atas selain membawa dampak perubahan bagi undang-undang perkawinan di Indonesia juga mengandung dimensi penegakan Hak Asasi Manusia. Putusan tersebut menjamin dan melindungi hak setiap wanita yang dihamili oleh soerang laki-laki, baik hamil dalam sebuah perkawinan maupun tidak. Selain itu, putusan tersebut juga menjamin dan melindungi hak-hak anak yang lahir dari kehamilan tersebut.

\section{Penagakkan HAM dalam Putusan Mahkamah Konstitusi Nomor 46/PUU-VIII/2010}

Pengubahan pasa 43 ayat (1) Undang-Undang No. Tahun 1974 di atas setidaknya bertujuan untuk:

1. Memberi legalitas hukum hubungan darah antara anak dengan ayah biologisnya, yakni bahwa hubungan darah antara anak dengan ayah biologisnya yang semula hanya merupakan sebuah realitas menjadi hubungan hukum sehingga memiliki akibat hukum.

2. Memberi perlindungan hukum atas hak-hak dasar anak, baik terhadap ayahnya dan keluarga ayahnya maupun lingkungannya.

3. Memberi perlakuan yang adil terhadap setiap anak yang dilahirkan meskipun perkawinan orang tuanya tidak (belum) ada kepastian.

4. Menegaskan adanya hubungan perdata setiap anak dengan ayah biologisnya dan keluarga ayahnya menurut hukum sebagaimana hubungan perdata dengan ibunya dan keluarga ibunya.

5. Menegaskan adanya kewajiban ayah menurut hukum (legal custady) memelihara setiap anak yang dilahirkan dari darahnya.

6. Melindungi hak waris anak dari ayahnya karena adanya hubungan darah, hak dan tanggung jawab satu sama lain.

7. Menjamin masa depan anak sebagaimana anak-anak pada umumnya.

8. Menjamin hak-hak anak untuk mendapat pengasuhan, pemeliharaan, pendidikan dan biaya penghidupan, perindungan dan lain sebagainya dari ayahnya sebagaimana mestinya.

9. Memberi ketegasan hukum bahwa setiap laki-laki harus bertanggung jawab atas tindakannya dan akibat yang timbul karena perbuatannya itu, 
dalam hal ini menyebabkan lahimya anak. Mereka tidak dapat melepaskan diri dari tanggung jawab tersebut. ${ }^{17}$

Putusan MK tersebut memiliki tujuan untuk melindungi dan menjamin hak setiap warga negara agar tidak dirugikan oleh pihak lain, terlebih oleh negara. Ada beberapa dimensi penegakan HAM dalam putusan MK No. 46/PUU$\mathrm{VIII/2010} \mathrm{di} \mathrm{atas,} \mathrm{yaitu:}$

\section{Jaminan dan perlindungan atas sebuah perkawinan}

Putusan Mahkamah Konstitusi No. 46/PUU-VII/2010 meberikan jaminan dan perlindungan terhadap Hak Asasi Manusia dalam hal hak untuk melanjutkan keturunan melalui sebuah perkawinan yang sah. Putusan MK ini merupakan penegasan terhadap pasal 28 B ayat (1) Undang-Undang dasar 1945 yang berbunyi:"Setiap orang berhak membentuk keluarga dan melanjutkan keturunan melelui perkawinan yang sah."18

Hai di atas juga menguatkan Pasal 16 ayat (1) Deklarasi Universal HAM yang berbunyi:

"Laki-laki dan Perempuan yang sudah dewasa, dengan tidak dibatasi kebangsaan, kewarganegaraan atau agama, berhak untuk menikah dan untuk membentuk keluarga. Mereka mempunyai hak yang sama dalam soal perkawinan, di dalam masa perkawinan dan di saat perceraian."19

Undang-Undang No. 39 tahun 1999 tentang Hak Asasi Manusia pasal 10 ayat (1) menyebutkan "Setiap orang berhak membentuk suatu keluarga dan melanjutkan keturunan melalui perkawinan yang sah." ${ }^{\text {"20 }}$ Putusan MK telah menguatkan jaminan dan perlindungan atas Hak Asasi Manusia sebagaimana tertuang dalam aturan-aturan di atas.

17 A. Mukti Arto, Diskssi Hukum Putusan Mabkatnab Konstitusi RI Nomor 46/PUUIIVV/2010 Tanggal 27 Pebriari 2012 Tentang Perubaban Pasal 43 UUP..., hal. 5-6.1

18 Undang-Undang Dasat Republik Indonesia tahun 1945 pasal 28 B ayat (1) pasca amandemen kedua.

19 Deklatasi Universal Hak Asasi Manusia tahun 1948 pasal 16 ayat (1).

${ }^{20}$ Undang-Undang No. 39 tahun 1999 tentang Hak Asasi Manusia pasal 10 ayat (1). 
Selain itu, dalam “Universal Islamic Declaration of Human Rights" pasal 19 poin (a) secara tegas disebutkan mengenai jaminan dan perlindungan setiap individu untuk melaksanakan pernikahan sesuai dengan agama dan tradisi yang berlaku:

'Every person is entitled to marry, to found a family and to bring up cbildren in conformity witb bis religion, traditions and culture. Every spouse is entitted to such rights and privileges and carries such obligations as are stipulated by the Law.' ${ }^{21}$

Dalam pasal 20 poin (b) juga disebutkan bahwa seorang istri mendapatkan jaminan dan perlindungan haknya untuk mendapatkan nafkah dan penghidupan yang layak, kasih sayang dan perlindungan psikis dan psikologis.

Every married woman is entitled to: receive the means necessary for maintaining a standard of living which is not inferior to that of her spouse, and, in the event of divorce, receive during the statutory period of watiing (iddab) meants of maintenance commensurate with ber busband's resources, for berself as well as for the cbildren she nurses or keeps, irrespective of ber oun financial status, eamings, or property that she may bold in ber own rights.22

Dalam "The Cairo Declaration on Human Rights in Islam, 5 August 1990" pasal 5 poin (a) juga disebutkan bahwa keluarga merupakan fondasi bagis ebuah masyarakat dan perkawinan merupakan landasan bagi sebuah banguna keluarga. Setiap laki-laki dan perempuan berhak untuk melaksanakan sebuah perkawinan tanpa melihat latar belakang primordialnya. "The family is the foundation of society, and marriage is the basis of making a family. Men and women bave the right to marriage, and no restrictions stemming from race, colour or nationality sball prevent them from exercising this right."23

Pasal 28 B ayat (1) UUD 1945 memberikan jaminan dan-perlindungan terhadap perkawinan yang sah. Berpijak pada pasal tersebut, Putusan MK memberikan jaminan dan perlindungan terhadap perkawinan setiap perkawinan yang sah, baik yang dicatatkan kepada Petugas Pencatat Nikah (PPN) maupun yang tidak atau pernikahan siri. ${ }^{24}$ Sebab, pernikahan yang tidak dicatatkan juga

${ }^{21}$ Saleem Azam, Universal Islamic Declaration of Haman Rights, Paris 21 Dhul Qaidah 140119 September 1981, Pasal 19 poin (a).

22 Ibid, Pasal 19 poin (b).

${ }^{23}$ The Cairo Declaration on Human Rights in Islam, 5 August 1990, pasal 5 poin (a)

${ }^{24}$ Petnikahan siri adalah pernikahan yang tidak dilakukan di hadapan Petugas Pencatatan Nikah serta tidak dicatatkan dalam lembar negara. 
merupakan perkawinan yang sah apabila telah dilaksanakan sesuai dengan ajaran agama masing-masing pihak yang melaksanakan perkawinan tersebut.

Mengenai pencatatan perkawinan, Mahkamah Konstitusi melalui putusan tersebut berpendapat bahwa pokok permasalahan hukum mengenai pencatatan perkawinan menurut peraturan perundang-undāngan adalah mengenai makna hukum (legal meaning) pencatatan perkawinan. Pencatatan bukanlan syarat sahnya suatu perkawinan. Diwajibkannya pencatatan perkawinan oleh. negara melalui peraturan perundang-undangan merupakan kewajiban administratif. ${ }^{25}$

Jadi, semua orang berhak untuk melaksanakan perkawinan. Setiap perkawinan tersebut mendapatkan hak dan jaminan perlindungan dari negara, baik yang dicatatkan maupun yang tidak. Negara wajib melindungi dan memberikan perlindungan hukum terhadap perkawinan dan akibat hukum yang timbul dari perkawinan tersebut.

\section{Jaminan dan perlindungan atas kelangsungan hidup seorang anak}

Selain melindungi dan menjamin hak setiap warga negara untuk melangsungkan keturunannya melalui sebuah perkawinan, putusan MK No. 46/PUU-VIII/2010 juga memberikan jaminan dan perlindungan terhadap kelangsungan hidup setiap anak yang lahir. Hal ini sebagai penguatan atas perlindungan hak anak sebagaimana tertuang dalam pasal 28 B ayat (2) UndangUndang Dasar Republik Indonesia tahun 1945 yang berbunyi: "Setiap anak berhak atas kelangsungan hidup, tumbuh dan berkembang serta berhak atas perlindungan dari kekerasan dan diskriminasi". ${ }^{26}$ Pasal 25 ayat (2) Deklarasi Universal Hak Asasi Manusia menyatakan: "Ibu dan anak-anak berhak mendapat-perawatan dan bantuan istimewa. Semua anak-anak, baik yang dilahirkan di dalam maupun di luar perkawinan, harus mendapat perlindungan sosial yang sama." ${ }^{27}$ Hal ini menunjukkan bahwa setiap anak yang lahir ke muka bumi, baik dari sebuah perkawinan maupun tidak berhak atas kehidupan yang

25 Putusan Mahkamah Konstituasi ..., hal. 33.

${ }^{26}$ Undang-Undang Dasar Republik Indonesia Tahun 1945 Pasal 28 B Ayat (2) pasca amandemen kedua.

${ }^{27}$ Deklarasi Universal Hak Asasi Manusia Tahun 1948 Pasal 25 Ayat (2). 
layak dan mendapatkan perlindungan dan terbebas dari segala macam diskriminasi.

Universal Islamic Declaration of Human Rights pasal 19 poin (c) menyebutkan bahwa seorang anak berkewajiban menjaga dan membimbing, mexawat serta melindungi anak dan istrinya:"Every busband is obligated to maintain bis wife and cbildren according to bis means. ${ }^{128}$ Selanjutnya, poin (d) menyebutkan mengenai hakhak seorang anak untuk mendapatkan pemeliharaan, perlindungan, bimbingan dan penghidupan yang layak, serta terbebas dari pekerjaan yang memberatkan bagi dirinya.

Every child bas the right to be maintained and property brought up by its parenits, it being forbidden that children are made to work, at an early age or that any burden is put on them which would arrest or barm their natural development."29 $\mathrm{Hal}$ senada juga disebutkan dalam "The Cairo Declaration on Human Rights in Islam, 5 August 1990" pasal 7 poin (a) yang menyebutkan: "As of the moment of birth, every child bas rights due from the parents, the society andthe state to be accorded proper nursing, education and material, bygienic and moral care. Both the fetus and the mother must be safeguarded and accorded special care. ${ }^{30}$

Penjelasan umum Undang-Undang RI Nomor 23 Tahun 2002 tentang Perlindungan Anak menyebutkan:

Bahwa anak adalah amanah sekaligus karunia Tuhan Yang Maha Esa, yang senantiasa harus kita jaga karena dalam dirinya melekat harkat, martabat, dan hakhak sebagai manusia yang hatus dijunjung tinggi. Hak asasi anak merupakan bagian dari hak asasi manusia yang termuat dalam Undang-Undang Dasar 1945 dan Konvensi Perserikatan Bangsa-Bangsa tentang Hak-Hak Anak. Dari sisi kehidupan berbangsa dan bernegara, anak adalah masa depan bangsa dan generasi penerus cita-cita bangsa, sehingga setiap anak berhak atas kelangsungan hidup, tumbuh, dan berkembang, berpartisipasi serta berhak atas perlindungan dari tindak kekerasan dan diskriminasi serta hak sipil dan kebebasan.

Pasal 2 undang-undang tentang perlindungan anak juga menyebutkan bahwa:

Penyelenggaraan perlindungan anak berasaskan Pancasila dan betlandaskan Undang-Undang Dasar Negara Republik Indonesia Tahun 1945 serta prinsip-

\footnotetext{
${ }^{28}$ Saleem Azam, Universal Islamic Declaration of Human Rights ..., Pasal 19 Poin (c).

${ }^{29}$ Ibid, Pasal 19 Poin (d).

30 The Cairo Declaration on Human Rights in Islam..., Pasal 7 Poin (a)
} 
prinsip dasar Konvensi Hak-Hak Anak meliputi: a. non diskriminasi; b. kepentingan yang terbaik bagi anak; $c$. hak untuk hidup, kelangsungan hidup, dan perkembangan; dan d. penghargaan tethadap pendapat anak." Lebih lanjut dalam pasal 3 disebutkan: "Perlindungan anak bertujuan untuk menjamin terpenuhinga hak-hak anak agar dapat hidup, tumbuh, berkembang, dan berpartisipasi secara optimal sesuai dengan harkat dan martabat kemanusiaan, serta mendapat perlindungan dari kekerasan dan diskriminasi, demi terwujudnya anak Indonesia yang betkualitas, berakhlak mulia, dan sejahtera." 31

Hak-haka seorang anak secara rinci diatur dalam Undang-Undang RI Nomor 23 Tahun 2002 pasal 4 sampai pasal 18. Secara singkat dapat disimpulkan bahwa setiap anak yang lahir Setiap anak berhak atas atas kasih sayang, perhatian, dan perlindungan orangtua, keluarga, masyarakat dan negara bagi pertumbuhan fisik dan mental serta perkembangan pribadinya, serta terbebas dari segala macam bentuk diskriminasi.

Ketentuan-ketentuan di atas merupakan jaminan dan perlindungan terhadap hak seorang anak atas kelangsungan hidup, tumbuh dan berkembang dan terbebas dari kekerasan dan diskriminasi dalam kehidupan sosial. Petlindungan tersebut terhadap semua anak yang lahir ke muka bumi ini, tanpa memandang ia lahir dari sebuah perkawinan maupun tidak. Dalam hal ini Mahkamah Konstitusi dalam putusannya tersebut menyatakan bahwa secara alamiah, tidaklah mungkin seorang perempuan hamil tanpa terjadinya pertemuan antara ovum dan spermatozoa baik melalui hubungan seksual (coitus) maupun melalui cara lain berdasarkan perkembangan teknologi yang menyebabkan terjadinya pembuahan. Oleh karena itu, tidak tepat dan tidak adiI manakala hukum menetapkan bahwa anak yang lahir dari suatu kehamilan karena hubungan seksual di luar perkawinan hanya memiliki hubungan dengan perempuan tersebut sebagai ibunya. Adalah tidak tepat dan tidak adil pula jika hukum membebaskan laki-laki yang melakukan hubungan seksual yang menyebabkan terjadinya kehamilan dan kelahiran anak tersebut dari tanggung jawabnya sebagai seorang bapak dan bersamaan dengan itu hukum meniadakan hak-hak anak terhadap lelaki tersebut sebagai bapaknya. Lebih-lebih manakala

31 Undang-Undang RI Nomor 23 Tahun 2002 Pasal 2-3. 
berdasarkan perkembangan teknologi yang ada memungkinkan dapat dibuktikan bahwa seorang anak itu merupakan anak dari laki-laki tertentu. ${ }^{32}$

Akibat hukum dari peristiwa hụkum kelahiran karena kehamilan, yang didahului dengan hubungan seksual antara seorang perempuan dengan seorang laki-laki, adalah hubungan hukum yang di dalamnya terdapat hak dan kewajiban secara bertimbal balik, yang subjek hukumnya meliputi anak, ibu, dan bapak. ${ }^{33}$ Putusan MK tersebut akan membawa implikasi di masyarakat, antara lain, adalah:

a. Anak mendapat perlindungan secara hukum dari ayahnya, meskipun perkawinan ayah dengan ibunya dipersoalkan/tidak jelas.

b. Setiap, ayah dapat dituntut tanggung jawab atas anaknya meskipun anaknya lahir di luar perkawinan.

c. Sekiranya kelahiran anak merupakan akibat perbuatan dosa orang tuanya, maka yang berdosa (bersalah) adalah orang tuanya dan sanksi hukuman hanya dapat diberikan kepada orang yang betsalah. ${ }^{34}$

Berdasarkanputusan tersebut, maka seorang anak yang lahir dari hubungan di luar perkawinan mendapat jaminan hak atas kelangsungan hidup berupa biaya hidup dari laki-laki yang telah menghamili ibunya. Hal ini merupakan implikasi dari hubungan keperdataan yang timbul dari adanya hubungan darah seorang anak dengan kedua orang tuanya. Berkaitan dengan jaminan kelangsungan hidup ini, Putusan MK tèrsebut membebankan kewajiban kepada setiap laki-laki yang menjadi ayah biologis dari seorang anak untk memenuhi hak anak yang berupa biaya hidup. Biaya hidup ini bagi anak yang lahir dari sebuah perkawinan yang sah adalah nafkah.

Berkaitan dengan nafkah atau biaya penghidupan anak, berdasarkan putusan MK Nomor 46/PUU-VII/2010 tidak diwujudkan dalam nafkah anak sebagaimana konsep hukum Islam, melainkan dengan bentuk kewajiban lain berupa penghukuman terhadap ayah biologisnya untuk membayar sejumlah

32 Putusan Mahkamah Konstituasi ..., hal. 34-35.

${ }^{33} \mathrm{Ibid}$, hal. 35.

34 A. Mukti Arto, "Diskusi Hukum Putusan Mahkamah Konstitusi RI Nomor 46/PUUIIIV/2010 Tanggal 27 Pebruari 2012 Tentang Perubahan Pasal 43 UUP'..., hal. 23. 
uang atau harta.gina keperluan biaya hidup anak yang bersangkutan sampai dewasa. Sebab ketentuan tentang nafkah anak dan waris itu berkaitan dengan nasab, padahạl anak luat kawin tidak bisa dinasabkan pada ayah biologisnya. ${ }^{35}$

Pemberian nafkah terhadap seorang anak merupakan konsekuensi dari adanya ikatan nasab seorang anak dengan ayahnya. Hubungan keperdataan menurut putusan MK Nomor 46/PUU-VIII/2010, tidak berlaku untuk ikatan nasab bagi warga negara yang beragama Islam. Oleh karena itu, maka anak yang lahir bukan dari sebuah perkawinan yang sah tidak berhak akan nafkah dari ayah biologisnya. Namun demikian, sang ibu dan anak berhak menuntut kepada ayah biologisnya tersebut untuk memberikan biaya hidup kepada sang anak sampai ia dewasa.

Undang-undang perkawinan mengatur mengenai kewajiban orang tua terhadap anak, hal ini diatur dalam pasal 45 UU Perkawinan No. 1 tahun 1974:

a. Kedua orang tua wajib memelihara dan mendidik anak-anak mereka sebaik-baiknya.

b. Kewajiban orang tua yang dimaksud dalam ayat (1) pasal ini berlaku sampai anak itu kawin atau dapat berdiri sendiri. Kewajiban mana berlaku terus meskipun perkawinan antara kedua orang tua putus.

\section{Jaminan dan perlindungan atas përlindungan dan kepastian hukum}

Putusan MK No. 46/PUU-VW/2010 memberikan jaminan dan perlindungan hukum kepada setiap anak yang lahir, baik Iahir dari sebuah perkawinan yang sah maupun tidak. Hạl ini merupakan implementasi dari pasal $28 \mathrm{D}$ ayat (1) Undang-Undang Dasar Republik Indonesia tahun 1945 yang berbunyi: "Setiap anak berhak atas pengakuan, jaminan, perlindungan, dan kepastian hukum yang adil serta perlakuan yang' sama di hadapan hukum". ${ }^{36}$ Atuaran tersebut menguatkan Deklarasi Universal Hak Asasi Manusia tahun 1948 pasal 6 yang berbunyi: 'Setiap orang berhak atas pengakuan di depan

35 Penjelasan Hakim MK, Akil Mochtar dalam diskusi dengan tema "Implementasi Ketentuan Anak Luar Kawin dalam UU Perkawinan Pasca Putusan MK' yang diselenggarakan oleh Hukumonline di Jakarta pada tanggal 29 Maret 2012.

${ }^{36}$ Undang-Undang Dasar Republik Indoriesia Tahun 1945 Pasal 28 D Ayat (1) pasca amandemen kedua. 
hukum sebagai manusia pribadi di mana saja ia berada." ${ }^{37}$ Jaminan perlindungan hukum juga disebutkan dalam pasal 7, "Semua orang sama di depan hukum dan berhak atas perlindungan hukum yang sama tanpa diskriminasi. Semua berhak atas perlindungan yang sama terhadap setiap bentuk diskriminasi yang bertentangan dengan Deklarasi ini, dan terhadap segala hasutan yang mengarah pada diskriminasi semacam ini." ${ }^{38} \mathrm{Hal}$ ini juga dikuatkan dalam Universal Islamic Declaration of Human Rights pasal 4 poin (a) yang menyebutkan: "Every person bas the right to be treated in accordance with the Law, and only in accordance with the Law." The Cair Declaration on Human Rights in Islam, 5 August 1990" pasal 19 poin (a) dan (b) menyebutkan: "(a) All individuals are equal before the law, without distinction between the ruler and the ruled. (b) The right to resort to justice is guaranteed to everyone." ${ }^{39}$

Pasal 3 ayat (2) undang-undang No. 39 tahun 1999 tentang Hak Asasi Manusi menyebutkan: "Setiap orang berhak atas pegakuan, jaminan, perlindungan dan perlakuan hukum yang adil serta mendapat kepastian hukum dan perlakuan yang sama di depan hukum." Singkatnya, setiap manusia berhak asa pelindungan hukum dan petlakuan yang sama di hadapan hukum tanpa memandang latar belakang status sosial dan latar belakang primordialnya.

Putusan MK tersebut, secara mutatis mutandis telah menimbulkan banyak perubahan hukum, antara lain, yaitu:

a. Mengubah hubungan darah anak dengan ayah bilogisnya yang semula hanya bersifat alamiah (sunnatullah) semata menjadi hubungan hukum yang mempunyai akibat hukum berupa hubungan perdata.

b. Adanya pengakuan secara hukum bahwa anak yang dilahirkan di luar perkawinan juga mempunyai hubungan perdata dengan ayah biologisnya dan keluarga ayahnya sebagaimana hubungan perdata anak dengan ibunya dan keluarga ibunya. Pengakuan secara hukum ini sebelumnya tidak ada.

c. Adanya tanggung jawab menurut hukum atas ayah terhadap anak yang dilahirkan akibat perbuatannya, meskipun anak itu lahir di, luar

${ }^{37}$ Dekiarasi Universal Hak Asasi Manusin Tahuin 1948 Pasal 6.

${ }^{38}$ Ibid, Pasal 7:

${ }^{39}$ The Cain Declaration on Human Rights in Islam..., Pasal 19 Poin (a) dan (b). 
perkawinan. Sebelumnya, ayah biologis tidak dapat digugat untuk bertanggung jawab atas anak biologisnya. ${ }^{40}$

Hubungan anak dengan seorang laki-laki sebagai bapak tidak semata-mata karena adanya ikatan perkawinan, akan tetapi dapat juga didasarkan pada pembuktian adanya hubungan darah antara anak dengan laki-laki tersebut sebagai bapak. Dengan demikian, terlepas dari soal prosedur/administrasi perkawinannya, anak yang dilahirkan harus mendapatkan perlindungan hukum. ${ }^{41}$

Mengenai hubungan keperdataan yang timbul dari hubungan darah, meliputi hubungan hukum, hak dan kewajiban antara anak dengan ayah dan ibunya yang dapat berupa: (1) hubungan nasab; (2) hubungan mahram; (3) hubungan hak dan kewajiban; (4) hubungan pewarisan (saling mewarisi) yang merupakan pelanjutan hubungan hak dan kewajiban karena nasab ketika mereka sama-sama masih hidup; dan (5) hubungan wali nikah antara ayah dengan anak perempuannya. ${ }^{42}$

\section{Pergulatan Putusan Mahkamah Konstitusi Nomor 46/PUU- VII/2010 dengan Hukum Islam}

Semua orang sepakat bahwa putusan Mahkamah Konstitusi Nomor 46/PUU-VIII/2010 secara tegas menegakkan konstitusi dan HAM. Namun demikian, dilihat dari perspektif ketentuan hukum Islamputusan tersebut menimbulkan pro-kontra di kalangan masyarakat. Ada kalangan yang mendukung, karena berpandangan bahwa putusan tersebut secara tidak langsung memberikan tanggung jawab yang besar terhadapo setiap laki-laki yang telah melakukan hubungan biologis dengan seorang wanita dan melahirkan anak. Baik hubungan biologis tersebut dalam suatu ikatan perkawinan yang sah dan dicatatakan dalam lembar negara di hadapan petugas maupun tidak. Bagi yang kontra, putusan tersebut telah memberikan hubungan keperdataan

40 A. Mukti Arto, "Diskusi Hukum Putusan Mahkamah Konstitusi RI Nomor 46/PUUIIIV/2010 Tanggal 27 Pebruari 2012 Tentang Perubahan Pasal 43 UUP” ..., hal. 7

41 Putusan Mahkamah Konstituasi ...., hal. 35.

42 A. Mukti Arto, Diskasi Hukum Putusan Mabkamab Konstitusi RI Nomor 46/PUUIIV/2010 Tanggal 27 Pebruari 2012 Tentang Perubaban Pasal 43 UUP ...., hal. 6. 
terhadap anak dengan bapaknya, padahal anak tersebut lahir di luar perkawinan yang sah sangat bertentangan dengan hukum Islam. Secara tidak langsung putusan tersebut telah melegalksan perzinaan.

Berikut ini akan dijelaskan mengenai hubungan keperdataan akibat hubungan darah yang. diberikan kepada anak yang lahir di luar perkawinan berdasarkan putusan Mahkamah Konstitusi Nomor 46/PUU-VII/2010. Sebagaimana telah disinggung di atas, bahwa hubungan keperdataan yang timbul akibat hubungan darah adalah:

\section{Hubungan Nasab}

Hubungan keperdataan yang ditetapkan dalam putusan Mahkamah Konstitusi No. -46/PUU-VIII/2010 tidak termasuk hubungan nasab sebagaimana nasab hubungan kewarisan dan perwalian sebagaimana yang diatur dalam fikih atau hukum Islam. Meskipun Ptusan MK tersebut berkaitan dengan Hukum Perkawinan secara umum yang berlaku bagi warga negara Indonesia, akan tetapi bagi yang beragama Islam, maka hubungan nasab seorang anak dengan ayahnya tetap berdasarkan adanya ikatan pernkawinan yang sah.

Hubungan nasab seorang anak zina atau anak yanga lahir bukan dari perkawinan yang sah hanya dinasabkan kepada ibunya, hal ini telah jelas dari hadis Nabi dan pendapat ulama. Hadis-hadis yang terkait dengan hubungan nasab anak zina antara lain hadis riwayat Bukharî dan Muslim:

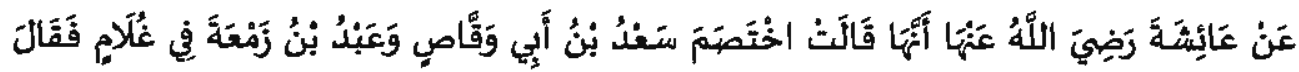

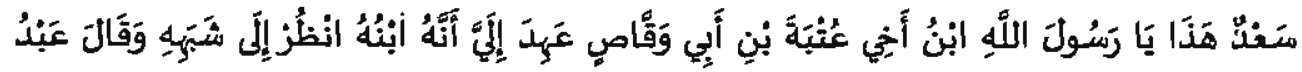

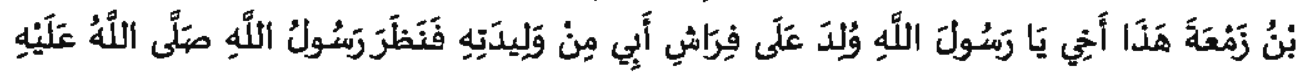

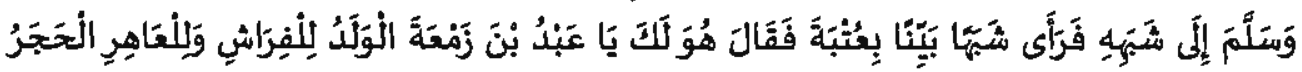

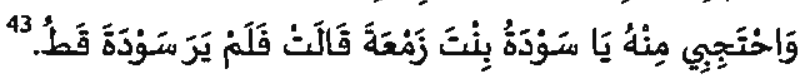

${ }^{43}$ Muhammad bin Ismail Abu Abdullah al-Bukhatî, Shohib al-Bukhânî, (Digital Library, Maktabah Syâmilab al-Isbdâr al-Tsânt, 2005), VI/2484, haidts nomor 6384; Imam Muslim, Sbobỉb Mustim, (Digital Library, Maktabah Syâmilah al-Ishdâr al-Tsâní, 2005), II/1080, haidts nomor 1457; Abu Daud, Sunan Abu Daud, (Digital Library, Maktabah Syâmilab al-Ishdâr al-Tsäní, 2005), VII/32, haidts nomor 2275; Imam al-Nasa'i, Sunan al-Nasa', (Digital Library, Maktabah Syamilab al-Ysbdar al-Tsâni, 2005), VI/491, haidts nomor 3484; Lihat Juga Imam al-Turmudzi, Sunan al-Turmudzi, 
Dari 'Aisyah ra bahwasanya ia berkata: Sa'd ibn Abi - Waqqash dan Abd ibn Zam'ah berebut tethadap seorang anak lantas Sa'd berkata: Wahai Rasulallah, anak ini adalah anak saudara saya 'Utbah ibn Abi Waqqash dia sampaikan ke saya bahwasanya ia adalah anaknya, lihatlah kemiripannya. 'Abd ibn Zum'ah juga berkata: "Anak ini saudaraku wahai Rasulullah, ia terlahir dari pemilik kasur (firasy) ayahku dari ibunya. Lantas Rasulullah saw melihat rupa anak tersebut dan beliau melihat keserupaan yang jelas dengan 'Utbah, lalu Rasul bersabda: "Anak ini saudaramu wahai 'Abd ibn Zum'ah. Anak itu adalah bagi pemilik kasur/suami dari perempuan yang melahirkan (firasy) dan bagi pezina adalah (dihuküm) batu, dan bethijablah darinya wahai Saudah Binti Zam'ah. Aisyah berkata: ia tidak pernah melihat Saudah sama sekali.

Hadis lain yang berkaitan dengan masalah ini adalah hadis riwayat Abu Daud yang menerangkan bahwa anak hazil zina dinasabkan kepada ibunya

$$
\text { قال النبي صهلى الله عليه وسلم في ولد الزنا لأهل أمه من كانوا. }
$$

Nabi SAW. bersabda tentang anak hasil zina: "Bagi keluarga ibunya ..."

Menurut Imam Syafi'i, anak zina tidak disabkan kepada bapaknya, akan tetapi kepada ibunya. Imam Syafi'i menjelaskan:

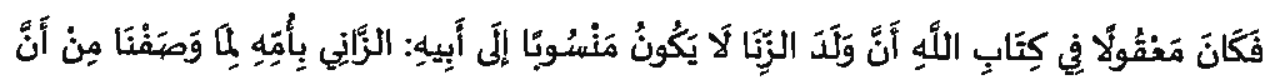

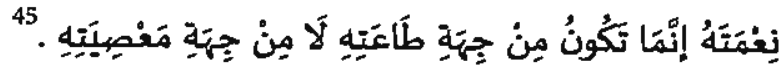

Sejalan dengan Imam Syafi'i, Imam Nawawi juga menjelaskan:

فلمان حكم ولد الزنا حكم ولد الملاعنة لاته ثابت النسب من أمه وغير ثابت النسب من أبيه فكان حكمه حمى وليد الملاعنة حكب.

- (Digital Libray, Maktabab Syâmilab al-Ishdâr al-Tsânit, 2005), IV/497, haidts nomor 1190; Tbnu Majah, Strnan Ibni Majah, (Digital Library, Maktabah. Syâmilah al-Isbdâr al-Tsâni, 2005), VI/243, haidts nomor 2084.

44 Abu Daud, Sunan Abu Dazd, (Digital Libraty, Maktabah Syâmilah al-Isbdâr al-Tsânî, 2005), VII/21, haidts nomor 2268 .

45 Imam al-Syâfi'i, Abkam Al-Quran, (Digital Libray, Maktabah Syâmilab al-Ishdâr al-Tsânî, 2005), I/hal. 322.

${ }^{46}$ Imam al-Nawawi, Al-Majmu', (Digital Libraty, Makłabah Syämilăb al-Isbdâr al-Tsânî, 2005), XVI/hal 105. 
Berdasarkan penjelasan di atas, dapat dimengerti dan dipahami bahwa pada dasarnya tidak ada perbedaan apalagi pertentangan antara putusan MK Nomor 46/PUU-VII/2010 dengan hukum Islam. Putusan MK tersebut meskipun memberikan jaminan adanya hubungan perdata seorang anak yang lahir di luar perkawinan yang sah dengan ibu dan ayah biologisnya, namun tidak memberikan hubungan nasab antara anak dengan ayahnya tersebut. Hal ini bisa dipahami, karena perzinaan tidak menimbulkan hubungan nasab. Para hakim MK, terutama Ketua MK, Moh. Mahfud MD dalam berbagai forum dan pertemuan selalu menjelaskan bahwa hubungan perdata berbeda dengan hubungan nasab. ${ }^{47}$ Mahfud menjelaskan bahwa anak yang lahir di luar nikah diakuinya memang tidak memiliki nasab, akan tetapi anak tersebut punya hak keperdataan.

\section{Hubungan Mahram}

Berdasarkan penjelasan pada poin a di atas, bahwa anak yang lahir dari hubungan di luar perkawinan yang tidak sah tidak mempunyai hubungan nasab dengan ayahnya, maka secara otomatis, anak tersebut juga tidak mempunyai hubungan maharam dengan ayahnya tersebut. Hubungan mahram antara anak dan ayahnya hanya akan timbul dengan ada ikatan nasab dari perkawinan yang sah sebagaimana telah dijelaskan di atas.

\section{Hak Mendapatkan Nafkah}

Hak nafkah atau biaya hidup anak yang lahir di luar perkawinan sebagaimana tercantụm dalam hubungan keperdataan berdasarkan putusan MK Nomor 46/PUU-VII/2010 tidak diwujudkan dalam nafkah anak sebagaimana

- konsep hukum Islam. Nafkah untuk anak di luar nikah adalah bentuk kewajiban

${ }^{47}$ Pada saat mengisi kuliah umum di Sekolah Tinggi Agama Islam Negeri (STAIN) Jurai Siwo Metro pada tanggal 30 Maret 2012 menjelaskan bahwa hubungan perdata yang dimaksud Putusan Mahkamah Konstitusi Nomor 46/PUU-VIII/2010 berbeda dengan hubungan nasab. Mahfud menjelaskan, hubungan keperdataan yang dimaksud MK tidak lantas menyebabkan anak yang lahir dari perzioaan menjadi anak yang punya hubungan nasab dengan bapak bilologisnya. Saat membuka pengajian Konstitusi di pondok pesantren Tebuireng Jombang, Sabtu 7 April 2012, Mahfud MD juga mengatakan bahwa berbeda antara hubungan nasab dengan hubungan keperdataan. Hubungan perdata artinya anak memiliki hak kepada.orang tuanya. Anak yang lahit di luar nikah diakuinya memang tidak memiliki nasab, akan tetapi anak tersebut punya hak keperdataan. 
lain berupa penghukumant terhadap ayah biologisnya untuk membayar sejumlah uang atau harta guna keperluan biaya hidup anak yang bersangkutan sampai dewasa. Sebab ketentuan tentang nafkah anak dan waris itu berkaitan dengan nasab, padahal anak luar kawin tidak bisa dinasabkan pada ayah biologisnya. ${ }^{48}$ Anak yang lahir bukan dari sebuah perkawinan yang sah tidak berhak akan nafkah dari ayah biologisnya. Namun demikian, sang ibu dan anak berhak menuntut kepada ayah biologisnya tersebut untuk memberikan biaya hidup kepada sang anak sampai ia dewasa. Biaya hidup sebagai konsekuensi adanya perlindungan dan jaminan hak untuk mendapatkan perlindungan dan kehidupan yang layak bagi istri dan setiap anak yang lahir ke muka bumi.

\section{Hubungan Waris}

Berkaitan dengan hak kewarisan anak dari ayahnya adalah anak yang memiliki hubungan nasab dengan ayahnya. Oleh karena itu yang dimaksud anak dalam hubungan kewarisan adalah anak yang ditunjuk dalam Pasal 42 UU Nomor 1 Tahun 1974 (Anak yang sab adalab anak yang dilabirkan dalam atau sebagai akibat perkawinan yang sab), termasuk di dalamnya anak yang lahir dalam ikatan perkawinan yang sah dan keabsahannya di akui oleh hukum karena dilakukan sesuai prosudur hukum, maupun dalam ikatan perkawinan yang sah tapi keabsahannya tidak diakui oleh hukum karena perkawinannya tidak memenuhi prosudur hukum, sepanjang keberadaannya tidak ada pihak lain yang keberatan. ${ }^{49}$

Hukum Islam mengatur mengenai kewarisan, bahwa kewarisan salah satunya disebabkan karena adanya hubungan nasab. Berdasarkan penjelasan di atas, anak yang Iahir di luar perkawinan yang sah tidak mempunyai hubungan nasab dengan ayah biologisnya, oleh karena itu dia tidak mendapatkan waris. Hadis Nabi yang diriwayatkan oleh Turmudzi:

48 Penjelasan Hakim MK, Akil Mochtar dalam diskusi dengan tema "Implementasi Ketentuan Arak Luat Kawin dalam UU Perkawinan Pasca Putusan MK" yang diselenggarakan oleh Hukumonline di Jakarta pada tanggal 29 Maret 2012.

49 Syamsul Anwar dan Isak Munawar, 'Nasab Anak di Luar Perkawinan Paska Putusan Mahkamah Konstitusi Nomor 46/PUU-VIU/2010 Tanggal 27 Pebruari 2012 menurut Teori Fikih dan Perundang-Undangan ...", hal. 3. 


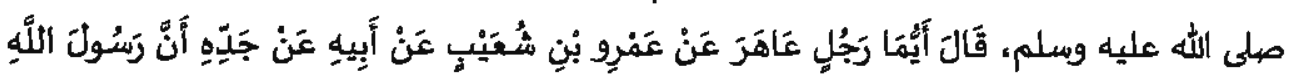

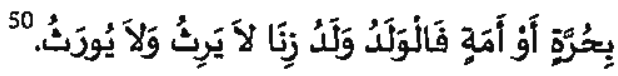

'Dari 'Amr ibn Syu'aib ra dari ayahnya dari-kakeknya bahwa rasulullah saw bersabda: Setiap orang yang menzinai perempuan baik merdeka maupun budak, maka anaknya adalah anak hasil zina, tidak mewarisi dan tidak mewariskan “

Berkaitan dengan ini al-Jashshash mengemukakan:

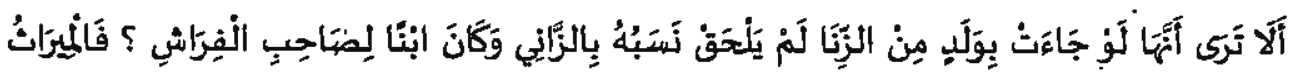

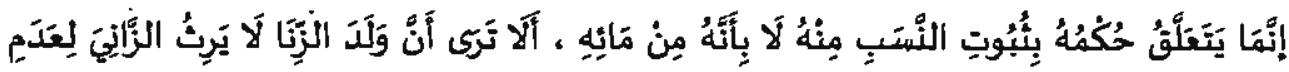

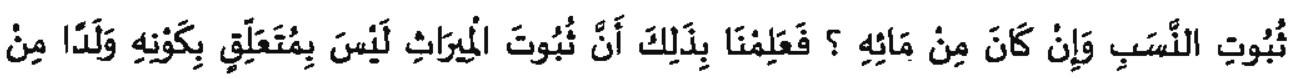

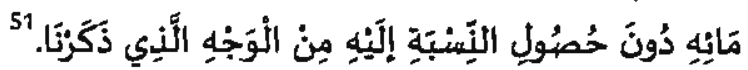

Senada dengan pendapat al-Jashshash tersebut, Imam Ibn 'Abidin mengatakan:

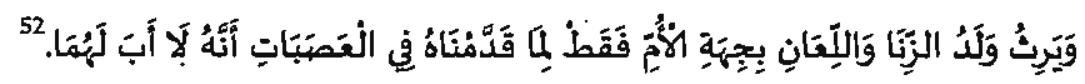

"Anak hasil zina atau li'an hanya mendapatkan hak waris dari pihak ibu saja, sebagaimana telah kami jelaskan di bab yang menjelaskan tentang Ashabah, karena anak hasil zina tidaklah memiliki bapak."

Menurut Akil, putusan MK tersebut hendaknya tidak dibaca sebagai pembenaran terhadap hubungan diluar nikah dan tidak bertentangan dengan Pasal 1 dan Pasal 2 UU No. 1 Tahun $1974 .^{53}$ Adapun yang berkaitan dengan

50 Sulaiman bin al-Asy'ats bin Syaddad bin al-'Amrai-Azdi Abu Daud, Sunan Abi Dasd, (Digital Library, Maketabah Syâmilab al-Isbdâr al-Tsâni, 2005), VII/223, hadits nomor 2259.

51 Abu Bakar al-Rari al-jashshash, Abkam al-Quran, (Digital Library, Maktabah Syâmilah alIshdâr al-Tsâni, 2005), VII/hal. 425.

52 Imam Tbn 'Abidin, Radd al-Mubtar 'ala al-Dur al-Mukbtar, (Digital Library, Maktabab Syâmilah al-Isbidâr al-Tsâni, 2005), XXIX/480. .

${ }^{53}$ Pasal 1: "Perkawinan ialah ikatan lahir bathin antara seorang pria dengan seorang wanita sebagai suami isteri dengan tujuan mernbentuk keluarga (numah tangga) yang bahagia dan kekal berdasarkan Ketuhanan Yang Maha Esa. Pasal 2 Ayat (1): "Perkawinan adalah sah, apabila dilakukan menurut hukum masing-masing agamanya dan kepercayaannya itu." Ayat (2) "Tiaptap perkawinan dicatat menurut peratutan penundang- undangan yang berlaku." 
kewarisan, maka hak keperdataannya tidak bisa diwujudkan dalam bentuk konsep waris Islam tapi dalam bentuk lain misalnya dengan konsep wasiat wajibah. ${ }^{54}$ Pada dasarnya, secara normatif, sebagaimana disebutkan dalam surat al-Baqarah ayat $180,{ }^{55}$ yang berhak akan wasiat wajibah adalah kedua orang tua yang tidak mendapatkan waris. Hanya saja, konsep wasiat wajibah ini ditafsirkan secara luas sebagai celah untuk memberikan harta warisan kepada mereka yang terhalang karena berbagai alasan, seperti perbedaan agama dalam keluarga. ${ }^{56}$

Puttusan MK Nomor 46/PUU-VIII/2010 yang memberikan hubungan keperdataan kepada anak lahir di luar nikah dengan anak biologisnya, termasuk hak waris, akan tetapi waris diartikan berbeda dengan aturan dalam hukum Islam sangatlah tepat. Penjelasan bahwa warisan yang diberikan kepada anak tersebut dilakukan dengan cara wasiat wajibah ${ }^{57}$ merupakan suatu upaya untuk menghindari adanya pertentangan antara putusan tersebut dengan hukum Islam, karena menurut hukum Islam kewarisan muncul karena adanya ikatan naab atau adanya perkawinan. Wasiat wajibah adalah suatu tindakan pembebanan oleh hakim atau lembaga yang mempunyai hak agar harta

54 Penjelasan Hakim MK, Akil Mochtar dalam diskusi dengan tema "Implementasi Ketentuan Anak Luar Kawin dalam UU Perkawinan Pasca Putusan MK", yang diselenggarakan oleh Hukumonline di Jakarta pada tanggal 29 Maret 2012.

55. "Diwajibkan atas kamu, apabila seorang di antara kamu kedatangan (tanda-tanda) maut, jika ia meninggalkan harta yang banyak, berwasiat untuk ibu-bapak dan katib kerabatnya secara ma'ruf (Ini adalah) kewajiban atas orang-orang yang bertakwa."

56 Lebih lanjut baca Suparman Usman dan Yususf Somawinata, Fiqib Mawaris: Huksm Kewarisan Islan, (Jakarta: Gaya Media Pratama, 2002), hal. 163-188. Menurut sementara ulama, pethatian Islam terhadap pembagian harta pusaka adalah melalui wasiat sebagaimana termaktub dalam surat al-Baqarah ayat 240 . Makanya wajar apabila ada kalangan ulama yang berpandangan bahwa ayat-ayat waris telah menasakb atau menganulir ayat-ayat wasiat. (Coulson, sebagaimana dikutip oleh Asep Sugiri, Wasiat untuk Ahli Waris: Kritik Ekstern dan Intem Otentisitas HadisHadis Larangan Wasiat untuk Ahli Waris dalam jumal $A L J A M I^{\prime} A H$, (Yogyakarta: UIN Sunan Kalijaga), Volume. 42, Nomor 2 tahun 2004, hal. 438-439.

57 Istilah wasiat wajibah sebenamya penemuan baru abad ke-20, sebelumnya tidak dikenal dalam fikih. Bahkan, mengkaitkan istilah wasiat wajibạh dengan anak atau orang tua angkat memang betul-betul penemuan hukum Indonesia. Istilah wasiat wajibah pertama kali diperkenalkan oleh ulama Mesir melalui hukum waris pada tahun 1946. Pada waktu itu, seorang anak yang lebih dahulu meninggal dunia, dan meninggalkan anak, maka si cucu itu menggantikan anaknya dalam mewarisi harta kekayaan kakeknya atau neneknya dengan cara memperoleh wasiat wajibah tidak lebih dari 1/3 harta. Lihat M. Atho Mudzar, Membaca Gelombang Ijtibad: Antara Tradisi dan Liberasi, (Yogyakarta: 'Titian Ilahi Press, 2000), hal. 163-164. 
seseorang yang telah meninggal dunia tetapi tidak melakukan wasiat secara suka rela agar diambil hak atau benda peningalannya untuk diberikan kepada orang tertentu dan dalam keadaan tertentu pula. ${ }^{58}$

\section{Perwalian.}

.Mengenai perwalian ${ }^{59}$ dalam pernikahan, Putusan MK tersebut tidak mengubah ketentuan Pasal 42 UUP yang menyakan: "Anak yang sah adalah anak yang dilabirkan dalam atau sebagai akibat perkawinan yang sab". Dengan demikian maka, ayah biologis tidak serta merta dapat bertindak sebagai wali nikah bagi anak perempuannya karena untuk menjadi wali nikah disyaratkan adanya legalitas bukum. Hubungan wali nikah merupakan hubungan resmi yang memerlukan legalitas hukum. Namun demikian apabila adanya hubungan nasab telah dapat dibuktikan melalui putusan pengadilan dan telah mempunyai akta kelahiran, maka ayahnya dapat bertindak sebagai wali nikah bagi anak perempuannya yang lahir di luar perkawinan. ${ }^{60}$

Berdasarkan pemaparan dan penjelasan di atas dapat kita pahami bahwa sebenarnya tidak ada pertentangan antara putusan Mahkamah Kosntitusi No. 46/PUU-VII/2010 dengan ketentuan dalam hukum Islam. Karena Putusan MK tersebut bersifat umum dan ada berbagai pengecualian dengan ketentuan yang ada dalam hukum agama yang diakui di Indonesia. Agar tidak menimbulkan pertentangan, pelaksanaan terhadap putusan tersebut harus menggunakan sudut pandang yang berbeda dengan ketentuan-ketentuan yang berlaku dalam hukum Islam, seperti pemberian nafkah dan hak waris sebagaimana telah dijelaskan di atas. hal. 184.

${ }^{58}$ Ahmad Rofiq, Hukum Islam dì Indonesia, (Jakarta: PT. Raja Grafindo Persada, 2003),

59 Wali secara etimologi adalah pelindung, penguasa, atau penolong. Arti umum perwalian adalah sesuatu yang bethubungan dengan wali. Wali pada waktu menikah mempunyai beberapa arti, diantaranya adalah pengasuh pengantin perempuan pada waktu menikah Abd. Rahman Ghazaly, Fiqih Munakabat, (Jakarta: Kencana, 2006), hal. 111.

${ }^{60}$ A. Mukti Arto, "Diskusi Hukum Putusan Mahkamah Konstitusi RU Nomor 46/PUUIIV/2010 Tanggal 27 Pebruati 2012 Tentang Perubahan Pasal 43 UUP ...", hal. 7-8. 


\section{E. Penutup}

Mahkamah Konstitusi No. 46/PUU-VIII/2010 pada dasarnya penegasan terhadap jaminan perlindungan Hak Asasi Manusia (HAM) terhadap setiap warga negara sebagaimana diamanatkan Undang-Undang dasar Republik Indonesia tahun 1945. Putusan tersebut meberikan jaminan dan perlindungan terhadap Hak Asasi Manusia dalam hal hak untuk melanjutkan keturunan melalui sebuah perkawinan yang sah, jaminan dan perlindungan terhadap kelangsungan hidup setiap anak yang lahir serta jaminan dan perlindungan hukum kepada setiap anak yang lahir, baik lahir dari sebuah perkawinan yang sah maupun tidak. Dengan adanya putusan tersebut, maka seotang laki-laki yang menggauli seorang wanita dan menyebabkan kehamilan dan melahirkan seorang anak berkewajiban memberikan biaya hidup, perlindungan dan terhadap wanita tersebut dan akan yang dilahirkannya, meskipun mereka tidak terikat dalam sebuah tali perkawinan yang sah.

Wanita tersebut mempunyai hubungan keperdataan dengan lelaki yang menghamilinya. Demikian juga, anak yang lahir dari hubungan di luar perkawinan tersebut juga mempunyai hubungan keperdataan dengan ibu dan ayah biologisnya. Hubungan keperdataan tersebut adalah hubungan nasab, hubungan mahram; hubungan hak dan kewajiban, hubungan pewarisan (saling mewarisi) dan hubungan perwalian. Penetapan hubungan keperdataan ini tidak bertentangan dengan ketentuan dalam hukum Islam, karena ada pengecualianpengecualian dan konsep pemberian hak yang betbeda dengan konsep nafkah dan waris dalam ketentuan hukum Islam. Pengecualian tersebut adalah tentang hubungan nasab, mahram dan perwalian. Sementara pemberian nafkah dan warisan menggunakan konsep berbeda dengan hukum Islam, yaitu dengan membebankan biaya hidup kepada ayah biologis sampai anak dewasa, dan hak waris diberikan dengan cara wasiat wajibah. 


\section{DAFTAR PUSTAKA}

'Abidin, Imam Ibn. 2005. Radd al-Mubtar 'ala al-Durr al-Mukbtar. Digital Library, Maktabab Syâmilab al-Isbdâr al-Tsâni.

Abu Daud. 2005. Sunan Abu Daud. Digital Library, Maktabah Syâmilab al-İsbdâr alTsânî.

Akil Mochtar. 2012. dalam diskusi dengan tema "Tmplementasi Ketentuan Anak Luar Kawin dalam UU Perkawinan Pasca Putusan MK" yang diselenggarakan oleh Hukumónline di Jakarta.

Al-Bukharî, Muhammad bin Ismail Abu Abdullah. 2005. Shohih al-Bukhârî. Digital Library, Maktabab Syâmilab al-Isbdâr al-Tsânî.

Al-Jashshash, Abu Bakar al-Razi. 2005. Abkam al-Quran. Digital Library. Maktabab Syâmilab al-Ishdâr al-Tsâni.

Al-Nasầî. 2005. Sunan al- Nasầî. Digital Library, Maktabab Syâmilab al-Ishdâr alTsânî.

Al-Nawawî. 2005. Al-Majmu'. Digital.Library, Maktabab Syâmilab al-Ishdâr al-Tsânî.

Al-Nisâbun̂, Imam Muslim. 2005. Sbobib Muslim. Digital Library, Maktabab Syâmilab al-Ishdâr al-Tsânî.

Al-Syâfi'i. 2005. Abkam Al-Quran. Digital Library, Maktabah Syâmilah al-Ishdâr alTsânt.

Al-Turmudzî. 2005. Sunan al-Turmudz̧. Digital Library, Maktabab Syâmilah alIshdâr al-Tsânî.

Anwar, Samsul dan Isak Munawar. 2012. "Nasab Anak di Luar Perkawinan Paska Putusan Mahkamah Konstitusi Nomor 46/PUU-VII/2010 Tanggal 27 Pebruari 2012 menurut Teori Fikih dan Perundang-Undangan." dikutip dari http://www.badilag.mahksamahagung.go.id.

Arifin, Bustanul. 1996. Pelembagaan Hukum Islam di Indonesia: Akar Sejarab, Hambatan, dan Prospeknya Jakarta: Gema Insani Press. 
Arto, A. Mukti. 2012. "Diskusi Hukum Putusan Mahkamah Konstitusi RI · Nomor 46/PUU-III/2010 Tanggal 27 Pebruari 2012 Tentang Perubahan Pasal 43 UUP." Dikutip dart http://www.badilag.mahkamahagung.go.id.

Asep Sugiri. 2004. "Wasiat untuk Ahli Waris: Kritik Ekstern dan Intern Otentisitas Hadis-Hadis Larangan Wasiat untuk Ahli Waris" dalam jurnal $A L J A M I ' A H$. Yogyakarta: UIN Sunan Kalijaga.

Deklarasi Universal Hak Asasi Manusia tahun 1948

Ghazaly, Rahman. 2006. Fiqib Munakahat. Jakarta: Kencana.

Mudzar, M. Atho. 2000. Membaca Gelombang Ijtibad: Antara Tradisi dan Liberasi. Yogyakarta: Titian Tlahi Press.

Nasution, Khoiruddin. 2002. Status Wanita di Asia Tenggara: Studi terbadap Perundang-Undangan Perkawinan Muslim Kontemponer di Malaysia dan Indonesia. Jakarta: INIS.

Nasution, Khoiruddin, 2005. "Pengaruh Gerakan Wanita terhadap Wacana "Hukum Islam: Studi Hukum Perkawinan di Indonesia" dalam jurnal $A L$ MAW ARID. Yogyakarta: FIAI UII.

Rofiq, Ahmad. 2003. Hukum Islam di Indonesia. Jakarta: PT. Raja Grafindo Persada.

Saleem Azam, Universal Islamic Declaration of Human Rights, Paris 21 Dhul Qaidah 140119 September 1981.

Satria, Rio. 2012. "Kritik Analisis Tentang Putusan Mahkamah Konstitusi Mengenai Uji Materil Undang-Undang Nomor 1 Tahun 1974 Tentang Perkawinan" dalam Makalah dipublish dalam laman http://www.badilag.mahkamahagung.go.id diunduh tanggal 12 mei 2012.

The Cairo Declaration on Human Rights in Islam, 5 August 1990.

Undang-Undang Dasar Republik Indonesia tahun 1945.

Undang-Undang No. 39 tahun 1999 tentang Hak Asasi Manusia.

Undang-Undang No. 39 tahun 1999 tentang Hak Asasi Manusia.Putusan Mahkamah Konstituasi No. 46/PUU-VIII/2010. 
192 Millab Vol. XII, No.1, Agustus 2012

Undang-Undang Republik Indonesia Nomor 1 Tahun 1974 tentang Perkawinan dan Kompilasi Hukum Islam.

Undang-Undang RI Nomor 23 Tahun 2002 tentang Perlindungan Anak Yusdani. 2011. Menuju Figih Keluarga Progresif. Yogyakarta: Kaukaba.

$\theta$ 